Original Research Paper

\title{
Meningkatkan Prestasi Belajar Sosiologi Siswa dengan Model Pembelajaran Kooperatif Team Games Tournament (TGT)
}

\author{
Suprapti ${ }^{1}$ \\ ${ }^{1}$ Sekolah Menengah Atas Negeri 8 Mataram, Indonesia.
}

*Corresponding Author: Suprapti, Sekolah Menengah Atas Negeri 8 Mataram, Indonesia; Email: suprapti.orbit@gmail.com

\begin{abstract}
Abstrak: Tujuan penelitian ini adalah untuk mengetahui efektifitas atau kemanjuran model pembelajaran kooperatif tipe Time Game Tournament (TGT) dalam upaya meningkatkan prestasi belajar siswa, serta mengetahui seberapa besar peningkatan hasil belajar siswa dengan menggunakan penggunaan model pembelajaran kooperatif tipe Time Game Tournament (TGT) pada materi mobilitas sosial. Pada penelitian ini, digunakan metode Penelitian Tindakan kelas (Classroom Action Research). Metode PTK ini digunakan karena metode ini memiliki peranan yang sangat penting dan strategis untuk meningkatkan mutu pembelajaran apabila diimplementasikan dengan baik dan benar. Penelitian ini dilaksanakan di SMA Negeri 4 Mataram pada semester 1 tahun pelajaran 2016/2017. Subjek penelitian adalah siswa kelas XI IPS 1 tahun pelajaran 2016/2017 yang berjumlah 18 siswa. Hasil penelitian menunjukkan bahwa penerapan model pembelajaran Team Game Tournament (TGT) dapat meningkatkan prestasi belajar peserta didik pada materi pokok perbedaan, kesataraan dan harmonisasi sosial, sub materi pokok struktur sosial dan diferensiasi sosial kelas XI IPS 1 SMA Negeri 4 Mataram Tahun Pelajaran 2016/2017.
\end{abstract}

Kata Kunci: Model Pembelajaran Kooperatif Tipe Time Game Tournament (TGT), Prestasi Belajar

\section{Pendahuluan}

Pendidikan merupakan hal yang sangat fundamental dalam kemajuan suatu bangsa karena melalui pendidikan akan tercipta manusia-manusia yang terampil dan berakhlak mulia. Pendidikan sendiri merupakan suatu usaha sadar untuk menumbuh kembangkan potensi yang ada di dalam diri manusia dengan cara mendorong dan memfasilitasi kegiatan belajarnya.

Pendidikan merupakan suatu usaha sadar dan terencana untuk mengembangkan setiap potensi yang ada dalam diri individu. Hal tersebut dapat dilakukan melalui suatu proses belajar yang menyenangkan. Penciptaan suasana belajar yang menyenangkan bagi peserta didik tentunya akan sangat berdampak positif bagi keberhasilan proses belajar. Hamalik (2013) berpendapat bahwa hasil belajar menunjuk pada prestasi belajar, sedangkan prestasi belajar itu merupakan indikator adanya dan derajat perubahan tingkah laku siswa. Dalam hal ini pendidik memegang peranan penting dalam keberhasilan suatu proses pembelajaran. Pendidik dapat menerapkan berbagai model pembelajaran inovatif yang relevan dengan materi yang diajarkan sehingga peserta didik mampu secara aktif mengembangkan secara optimal setiap potensi yang ada di dalam dirinya.

Dalam UU No.20 tahun 2003 tentang Sisdiknas di atas dijelaskan bahwa pendidikan memerlukan suasana balajar dan proses pembelajaran. Belajar dapat diartikan sebagai suatu perubahan tingkah laku akibat dari diperolehnya pengalaman melalui interaksi dengan lingkungan. Lingkungan belajar individu meliputi lingkungan keluarga, sekolah dan masyarakat dimana ketiganya saling berhubungan. Slameto (2013) menyatakan bahwa secara psikologis, belajar merupakan suatu proses perubahan yaitu perubahan tingkah laku sebagai hasil dari interaksi dengan lingkungannya dalam memenuhi kebutuhan hidupnya. Purwanto (2013) Belajar merupakan suatu perubahan dalam tingkah laku, dimana perubahan itu dapat mengarah kepada tingkah laku yang lebih baik, tetapi juga ada 
kemungkinan mengarah kepada tingkah laku yang lebih buruk.

Pembelajaran merupakan suatu proses interaksi antara pendidik dan peserta didik yang didukung sumber belajar pada suatu lingkungan belajar. Pembelajaran menekankan pada proses belajar individu. Pihak yang terlibat dalam proses pembelajaran, yaitu pendidik (perorangan/kelompok), serta peserta didik (perorangan, kelompok atau komunitas) yang saling melakukan interaksi edukatif. Keberhasilan peserta didik menangkap materi belajar tergantung pada proses pembelajaran yang diberikan oleh guru kepada peserta didik. Agar proses pembelajaran dapat berjalan dengan maksimal maka guru harus bisa menggunakan metode belajar yang tepat bagi siswa. Pembelajaran inovatif yang disesuaikan dengan materi yang akan diajarkan sangat penting untuk dilakukan karena akan membuat suasana belajar lebih menyenangkan dan menghindarkan siswa dari kejenenuhan.

Berawal dari proses pembelajaran yang tidak optimal maka keterserapan ilmu menjadi tidak optimal dan hal ini akan berdampak pada prestasi belajar siswa. Guru cenderung menggunakan model pembelajaran ceramah dalam setiap proses pembelajaran. Suara guru dalam menjelaskan materi pelajaran melalui metode ceramah pun pelan mengakibatkan antusias belajar siswa selama mengikuti proses pembelajaran menjadi berkurang. Siswa cenderung tidak mendengarkan penjelasan yang disampaikan oleh guru.

Berdasarkan identifikasi di atas guru harus melakukan refleksi dan menggunakan model pembelajaran yang lain yaitu model pembelajaran kooperatif tipe Team Games Tournament (TGT). Dalam pembelajaran kooperatif siswa akan belajar dalam sebuah tim kecil dengan demikian komunikasi yang terjalin dapat lebih efektif dan efisien. Siswa akan menjadi lebih aktif. Mereka akan belajar menyelesaikan masalah yang mereka hadapi, akan lebih berani bertanya, mengungkapkan ide atau gagasan dan meraka juga akan belajar untuk saling menghargai satu sama lain. Pembelajaran kooperatif adalah suatu model pembelajaran dimana sistem belajar dan bekerja dalam kelompok-kelompok kecil yang berjumlah 46 orang secara kolaboratif sehingga dapat merangsang siswa lebih bergairah dalam belajar (Isjoni, 2013).

\section{Metode}

Pada penelitian ini, digunakan metode Penelitian Tindakan kelas (Classroom Action Research). Metode PTK ini digunakan karena metode ini memiliki peranan yang sangat penting dan strategis untuk meningkatkan mutu pembelajaran apabila diimplementasikan dengan baik dan benar. Menurut John Elliot (1991), penelitian tindakan kelas sebagi kajian dari sebuah situasi sosial dengan kemungkinan tindakan untuk memperbaiki kualitas situasi sosial tersebut. Penelitian ini dilaksanakan di SMA Negeri 4 Mataram pada semester 1 tahun pelajaran 2016/2017 yaitu dari tanggal 19 September s/d 26 September 2017. Subjek penelitian adalah siswa kelas XI IPS 1 tahun pelajaran 2016/2017 yang berjumlah 18 siswa.

Pelaksanaan Penelitian Tindakan Kelas (PTK) ini direncanakan dalam 2 siklus yaitu siklus I yang terdiri atas penyajian materi, pelaksanaan model pembelajaran kooperatif teams games tournament (TGT), dan pelaksanaan evaluasi. Pada Siklus digunakan model John Elliot. Pada model ini tahapan penelitian dibagi menjadi empat tahap: (1) perencanaan, (2) pelaksanaan, (3) pengamatan, dan (4) refleksi, kemudian dilanjutkan ke siklus berikutnya. Hubungan keempat komponen itu dipandang sebagai satu siklus. Secara visual hubungan keempat komponen dalam sistem siklus dapat di gambarkan sebagai berikut :

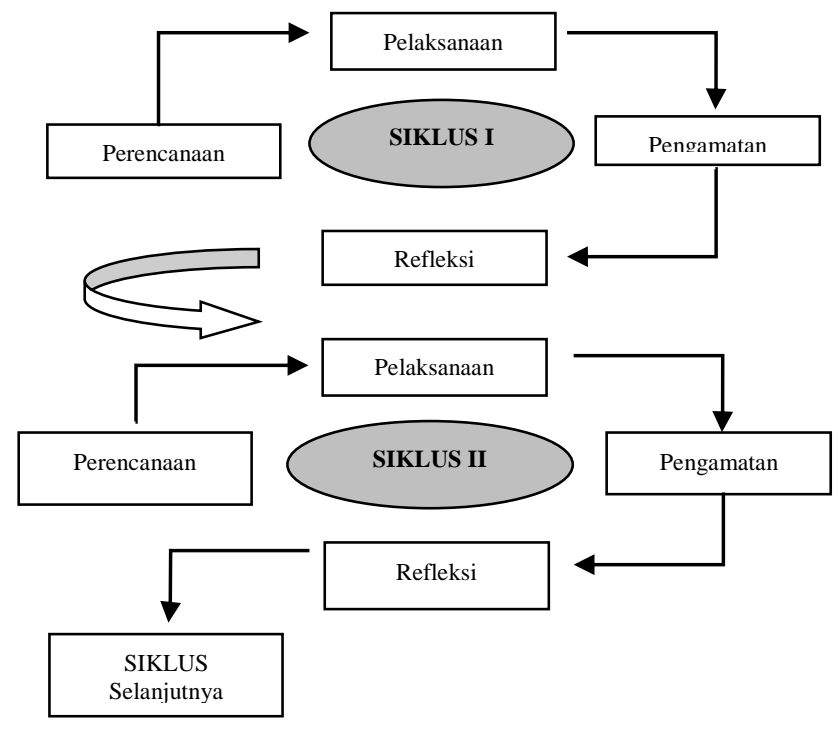

Gambar 1. PTK Model John Elliot 
Teknik pengumpulan data yang akan digunakan adalah studi pustaka, teknik observasi, dan tes. Analisis data adalah penelaahan dan penguraian atas data hingga menghasilkan simpulan-simpulan.

\section{Hasil dan Pembahasan}

Pembelajaran merupakan kegiatan terencana yang mengkondisikan/ merangsang seseorang untuk dapat belajar dengan baik agar mencapai tujuan pembelajaran. Hal tersebut baru akan terjadi apabila guru mengetahui dengan baik objek yang akan diajarkannya. Sehingga guru dapat memberikan materi dengan baik dalam proses pembelajaran. Kegiatan pembelajaran yang efektif dapat menunjang keberhasilan belajar peserta didik secara optimal. Proses pembelajaran efektif dilengkapi dengan model pembelajaran yang memadai sehingga dapat menunjang keberhasilan penguasaan materi pada diri peserta didik secara optimal. Demi tercapaianya tujuan pembelajaran tersebut, maka guru perlu merencanakan kegiatan pembelajaran secara sistematis dengan memanfaatkan segala sesuatu untuk kepentingan proses pembelajaran.

Penelitian ini merupakan penelitian tindakan kelas dengan menerapkan model pembelajaran kooperatif tipe Team Game Tournament pada sub materi pokok struktur sosial dan diferensiasi sosial. Berdasarkan hasil observasi, tes kognitif, wawancara dan dokumentasi pembelajaran dengan menggunakan model pembelajaran kooperatif tipe Team Game Tournament (TGT) dapat meningkatkan prestasi belajar peserta didik meliputi aspek kognitif dan aspek afektif.

\section{Siklus I}

Pada pembelajaran siklus I, peserta didik dibagi menjadi 8 kelompok berdasarkan hasil tes pra tindakan dimana masing-masing kelompok terdiri dari 4 peserta didik. Pada proses pembelajaran siklus I guru menekankan agar peserta didik aktif mencari informasi dan pengetahuan, sedangkan guru hanya sebagai fasilitator. Dalam proses pembelajaran, kegiatan pembelajaran berpusat pada peserta didik. Peserta didik dituntut untuk berpartisipasi aktif berdiskusi dan berkerjasama dalam kelompok untuk memecahkan masalah dan menemukan solusi.
Dari hasil evaluasi siklus I dapat diketahui bahwa rata-rata siswa mencapai 75,28 , sedangkan nilai terendah adalah 55 dan nilai tertinggi adalah 90. Selanjutnya ditinjau dari penguasaan bahan ajar atas dasar (KKM) pada siklus I yang ditetapkan 75 dapat dapat diketahui bahwa siswa yang berhasil mencapai nilai KKM: 75 (Tuntas) adalah sebanyak 12 siswa $(66,67 \%)$, sedangkan siswa yang belum mencapai nilai KKM : 75 (TidaK Tuntas) adalah sebanyak 6 sswa (33,33\%). Dengan demikian dapat dikatakan bahwa pelaksanaan siklus I belum berhasil seperti yang diharapkan sehingga diperlukan pelaksanaan siklus II.

\section{Siklus II}

Tindakan pada siklus II lebih difokuskan untuk penyempurnaan dan perbaikan terhadap kendalakendala yang terdapat pada siklus I. pada siklus II pembagian kelompok dilakukan berdasarkan capaian siswa selama siswa. Pada siklus II guru memberikan kesempatan peserta didik untuk memecahkan masalah secara berkelompok dalam diskusi.

Dari hasil evaluasi pada siklus II, dapat diketahui bahwa nilai rata-rata siswa mencapai 78,89 artinya meningkat 3,61 poin dari nilai evaluasi siklus I yang rata-ratanya mencapai 75,28. Sedangkan nilai terendah pada evaluasi siklus I masih mencapai 55 akhirnya meningkat menjadi 63. Demikian juga nilai tertinggi yang sebelumnya pada siklus I mencapai 90 masih tetap dipertahankan 90 pada siklsu II.

Atas dasar pengolahan nilai siklus II dapat diketahui bahwa siswa yang berhasil mencapai nilai KKM: 75 (Tuntas) adalah sebanyak 15 siswa $(83,67 \%)$, artinya meningkat dari hasil evaluasi pada siklus I yang hanya mencapai 12 siswa $(66,67 \%)$. Sedangkan siswa yang belum mencapai nilai KKM: 75 (Tidak Tuntas) adalah sebanyak 3 siswa (16,33\%), artinya menurun dari hasil evaluasi belajar pada siklus I yang mencapai 6 siswa (33,33\%). Dengan demikian pelaksanaan siklus II dalam penelitian ini dapat dikatakan telah berhasil meningkatkan prestasi belajar siswa kelas XI IPS 1 SMA Negeri 4 Mataram.

Keberhasilan penggunaan model pembelajaran kooperatif tipe Team Game Tournament (TGT) dalam penelitian ini dalam rangka meningkatkan prestasi belajar siswa kelas XI IPS 1 SMA Negeri 4 Mataram diperkuat dengan pemberian angket terhadap siswa yang berbunyi "Apakah 
menyenangkan atau membosankan proses pembelajaran yang menerapkan model pembelajaran kooperatif tipe Team Game Tournament (TGT)?". Jawaban siswa adalah 10 siswa menjawab sangat menyenangkan, 5 siswa menjawab agak menyenangkan, 2 siswa menjawab agak membosankan, dan 1 siswa menjawab membosankan.

Pada pertanayaan kedua yang berbunyi "Apakah sulit atau mudah mempelajari materi mobilitas sosial yang menggunakan model pembelajaran kooperatif tipe time game tournament (TGT)?", jawaban siswa adalah 12 siswa menjawab sangat mudah, 5 siswa menjawab agak mudah, 1 siswa menjawab agak sulit, dan tidak ada siswa menjawab sulit.

Atas dasar hasil angket pertanyaan 1 dan 2 menunjukkan bahwa penerapan model pembelajaran kooperatif tipe Team Game Tournament (TGT) berdampak baik terhadap siswa. Dengan demikian dapat disimpulkan bahwa mempelajari materi mobilitas sosial dengan menggunakan model pembelajaran kooperatif tipe Time Game Tournament (TGT) termasuk sangat menyenangkan dan mudah dipahami oleh siswa.

\section{Kesimpulan}

Berdasarkan hasil dari penelitian yang telah dilakukan, maka dapat diambil kesimpulan bahwa penerapan pembelajaran Team Game Tournament (TGT) dapat meningkatkan prestasi belajar peserta didik pada materi pokok perbedaan, kesataraan dan harmonisasi sosial, sub materi pokok struktur sosial dan diferensiasi sosial kelas XI IPS 1 SMA Negeri 4 Mataram Tahun Pelajaran 2016/2017.

\section{Saran}

Berdasarkan hasil penelitian yang telah dilakukan, maka dikemukakan beberapa saran yaitu guru hendaknya dapat memilih dan menggunakan model pembelajaran yang tepat, dan penelitian ini dapat dijadikan sebagai bahan acuan bagi peneliti selanjutnya. Kemudian sekolah hendaknya mendorong guru untuk melakukan penelitian tindakan kelas sebagai upaya perbaikan pembelajaran agar proses pembelajaran berlangsung dengan berkesinambungan.

\section{Daftar Pustaka}

Hamalik, Oemar. 2013. Proses Belajar Mengajar. Jakarta: Bumi Aksara

Isjoni. 2013. Cooperative Learning Efektivitas Pembelajaran Kelompok. Bandung: Alfabeta.

John, Elliot. 1991. Action Research for Educational Change. Philadelphia: Open University Press.

Purwanto. 2013. Evaluasi hasil belajar.Yogyakarta: Pustaka Pelajar

Slameto. 2013. Belajar dan Faktor-Faktor yang Mempengaruhinya. Jakarta: PT Rineka Cipta. 